Marijan Dović

ZRC SAZU Institute of Slovenian Literature

and Literary Studies

Slovenia
UDC 050.488SVETOKRET

050.488TANK

821.163.6.02ZENITIZAM

doi $10.5937 / Z b A k U 2109091 \mathrm{D}$

Original scientific paper

\title{
From Svetokret to Tank: Zenitism and the Slovenian Interwar Avant-Garde (1921-1927)
}

\begin{abstract}
In January 1921, Svetokret, the first radical avant-garde magazine in the newly founded Kingdom of Serbs, Croats, and Slovenes, was launched in Ljubljana by Virgil Poljanski (1898-1947). This unique edition was a herald of Zenit (1921-1926), a mouthpiece of the ambitious zenitist movement, embodied by Poljanski's elder brother Ljubomir Micić (1895-1971). This article examines the dynamics of relations between the protagonists of the Slovenian interwar avant-garde and the leading zenitists, as documented in correspondence, newspaper reports, and, above all, in the magazine and publishing production of the avant-garde movements themselves. In the first phase, these relations revolved around Anton Podbevšek and his group, which had gathered around the Trije labodje magazine (The Three Swans, 1922), but cooperation remained limited. In the second, more productive phase, zenitist ideas were partially embraced by the group of Slovenian constructivists led by Avgust Černigoj and Ferdo Delak. Zenitism and its magazine were certainly an important source of information and inspiration for Slovenian avant-garde artists (e.g., the poet Srečko Kosovel) but, despite several attempts, the cooperation did not produce lasting results before Zenit was banned in 1926. In 1927, the Ljubljana-based Tank magazine, edited by the ambitious Delak and supported by Micić, tried to continue the zenitist legacy. Unfortunately, its existence was short-lived.
\end{abstract}

Keywords: Svetokret, Zenit, Tank, Slovenian interwar avant-garde, Zenitism

In January 1921, exactly one hundred years ago, Svetokret (World-Turning), „a magazine for the expedition to the North Pole of the human spirit," the first radically avant-garde periodical in the new Yugoslav state, appeared in Ljubljana. ${ }^{1}$ Its publisher and sole author was Virgil Poljanski (1898-1947), a rebellious cultural proletarian, an avant-garde enfant terrible, that is said to have been dubbed a „mad dog" in Ljubljana precisely because of this publication. This episode from Slovenian (or Yugoslav) literary history is almost forgotten today because Svetokret remained a one-off gesture:

1 This article was written as part of the „Literarnozgodovinske, literarnoteoretične in metodološke raziskave," "research programme (P6-0024), supported by the Slovenian Research Agency. 
a magazine printed in (Latin-alphabet) Serbian found it difficult to take root in Slovenia, and its fieriness was probably shocking even to the young Slovenian avant-garde artists that surfaced in Novo Mesto and Ljubljana in the autumn of 1920. At the same time, however, this unexpected, bizarre phenomenon rightly arouses interest: first, because Svetokret can be seen as a harbinger of zenitism, an internationally recognized avantgarde movement embodied by Ljubomir Micić (1895-1971), the brother of Virgil Poljanski and editor of Zenit (Zenith), and, second, because from Svetokret and Trije labodje (The Three Swans) to Tank one can trace how the protagonists of the Slovenian avant-garde of the 1920s - from Marij Kogoj, the Kralj brothers, and Anton Podbevšek's Novo Mesto group to Srečko Kosovel, Ferdo Delak, and Avgust Černigoj's constructivists—responded to the initiatives of the more ambitious Yugoslav movement.

\section{SVETOKRET

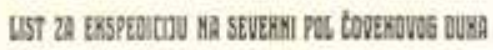

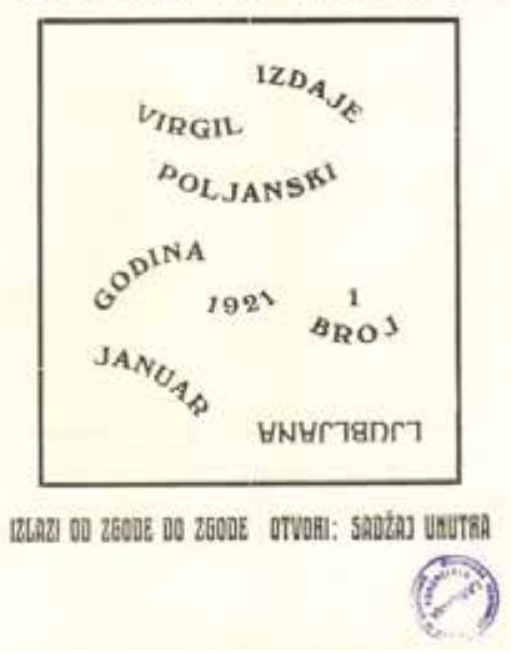

\section{Figure 1. Title page of Svetokret (January 1921)}

January 1921: Poljanski and the „Expedition to the North Pole of the Human Spirit“

Svetokret opens with the aggressive prologue „Here I am!“ in which Poljanski’s unconventional appearance on the cultural scene is articulated almost like a declaration of war: „I carry a whip to lash even the thickest skin to blood . . . And I will sting, I will stab wildly into their barrel-shaped bellies and-pierce through. ... I will strike with 
steel cyclopean force and-strike down" (Poljanski, 1921: 4). ${ }^{2}$ This is followed by the "Manifesto," in which the spiritual revolutionary proclaims that it will be necessary to leave the „twenty stinking centuries" far behind, and exclaims: „Long live the free human spirit! Glory to the new man! Let it be a glorious revolution of the spirit in October, when all the old forms will fall, like dry and pale leaves!“ (ibid.).

Where did the angry author of Svetokret, a rebellious poet inspired by the postwar avant-garde utopia of total (spiritual) revolution, come from? Born in 1898 to a poor Serbian family in the Croatian village of Sošice, he was educated in Karlovac and then in Zagreb, where he did not finish school because he was expelled in 1915 for parodying the Croatian anthem. In 1917, he began working in theatre. After the war, he was for some time at the Slovenian theatre in Trieste and later, in 1920, he appeared in Ljubljana. Poljanski did many things in his life: he was an actor and theatre critic, poet and writer, lecturer and performer, founder of avant-garde magazines, painter, illustrator, and designer. Above all, however, he was the second pillar of Zenit and a tireless international promoter of the zenitist movement-until his symbolic public divorce from literature and Yugoslavia in 1927. ${ }^{3}$ All of this was still waiting for Poljanski when, as a young man of twenty-two in Ljubljana, he first publicly distinguished himself as a radical avant-garde writer. ${ }^{4}$ Yet, even his debut is visibly marked by a megalomaniacal, messianic utopianism: the belief that the moment of a total break with the old and a radical spiritual renewal has arrived, accelerated by the agony of the First World War and the Bolshevik coup in Russia. Already in Svetokret, Poljanski fashions himself as an archetypal furious man to an extent that is unparalleled in the Yugoslav arts (cf. Rogic Musa, 2010: 71).

Little is known about Poljanski's early theatrical engagements in Trieste and later in Ljubljana. It can be inferred that the young man with no formal training was employed on a part-time basis. In the estate of Ljubomir Micic there is a document from January 1920 confirming his payment of a six-month membership fee for the Ljubljana branch of the actors' association. ${ }^{5}$ Poljanski (listed as „Mr. Mičič“") certainly appeared at least in Ivan Cankar's play Pohujšanje v dolini Šentflorjanski (Scandal in the St. Florian Valley), staged by Osip Šest for the National Theatre in Ljubljana in the 1920/21 season, playing the bit role of the Traveler (Popotnik). It seems entirely possible, as Dragan Živadinov believes, that Poljanski displayed ,elegant eccentricity and experimentation in his lifestyle," but it is less likely that the (precarious) actor would already be giving

\footnotetext{
2 All translations from Slovenian and Serbian to English are by the author.

3 On Poljanski's turbulent life, cf. Golubović and Subotić (2008: 361-363), and for the new findings on his final years in Paris cf. Todorović (2015).

4 On his polemical debut in Maska in 1920, which precedes the Svetokret episode, cf. Pranjić in this issue. 5 I am thankful to Irina Subotić for this information.
} 
public lectures at this time. As shall be seen, this happened a few years later, when Poljanski returned to Ljubljana, this time as a fully formed avant-garde cosmopolitan.

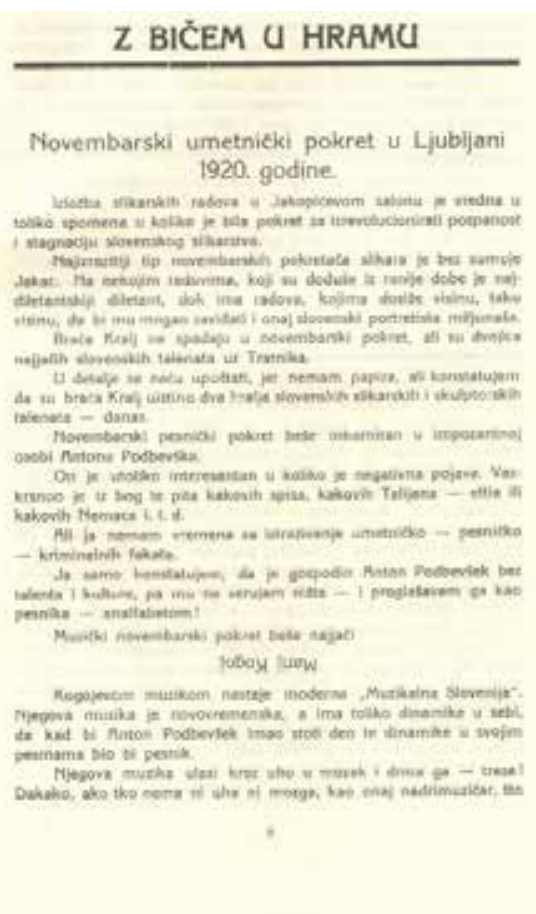

\section{Figure 2. Virgil Poljanski's critique of the Ljubljana debut of the „November Movement" (Svetokret 1921/1, p. 9)}

In January 1921, however, Poljanski managed to get Svetokret printed. This issue is all the more interesting because it contains a critique of the first appearance of the Slovenian historical avant-garde, called the „November Movement“ by Poljanski (better known today as the "Novo Mesto Spring"), which raised a lot of dust in Ljubljana at the time. As an avant-garde artist, Poljanski approaches the movement sympathetically, but he remains critical, sometimes even caustic. First, he comments on the exhibition in the Rihard Jakopič pavilion. He finds Božidar Jakac, the major new painter of the Novo Mesto group, utterly amateurish in his early works but rapidly improving in his later paintings, whereas the brothers France and Tone Kralj, who do not belong to the movement, are praised as the true kings among Slovenian visual artists. On the $12^{\text {th }}$ November, Poljanski apparently attended the infamous poetic debut of Anton Podbevšek at the Ljubljana National Theatre. Surprisingly, the fellow Slovenian avant-garde poet did not impress him: 
The November Poetry Movement was incarnated in the imposing person of Anton Podbevšek. / He is only interesting as a negative phenomenon. He was resurrected from God knows what kind of writings, what kind of Italians, -etties, or what kind of Germans, etc. / But I have no time to research artistic-poetic-criminal facts. I just state that Mr. Podbevšek is without talent and culture, and therefore I do not trust him at all—and I declare him, as a poet, illiterate! (Poljanski, 1921: 9)

Poljanski formed a completely opposite opinion about Marij Kogoj, another future member of ,the swans":

Kogoj's music creates a modern „Musical Slovenia.“ His music is modern, and it has so much dynamism in it that, if Anton Podbevšek had a hundredth part of that dynamic in his poems, he would be a poet. / His music enters through the ear into the brain and shakes it-it quakes! Of course, if someone has neither ear nor brain . . . then it is not music for him, but empty banging: bim, bam, bum!!!. . Long live Marij Kogoj! (ibid.: 9-10)

Poljanski also published some of his poems in Svetokret, which, unlike his later poetry, are much less radical than his manifestos. ${ }^{6}$ On the back cover he also announced the contents of the second issue, from which one can infer that he seriously intended to continue the magazine. However, Poljanski never managed to publish the second issue of Svetokret; to be honest, it even remains a mystery how he was able to finance the printing of the first issue. The modest reach that such a one-off issue could have at best gives Svetokret the stamp of an advertising pamphlet, rather than a genuine magazine. On the back cover, however, one also finds the announcement of the forthcoming Zenit, an international magazine of art and culture, to be published in Zagreb on the $1^{\text {st }}$ February. Edited by Poljanski's brother Ljubomir Micić, this magazine was conceived much more seriously both editorially and economically, as evidenced by the invitation to preorder, the publication of prices, and the address of the editorial office (Hatzova ulica 9/I). As it turned out overtime, Zenit actually cut more decisively into domestic matters, as well as into the international cultural field.

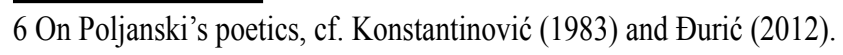


February 1921: Micić and the Balkan „Barbarian-genius“

Zenit, announced by Poljanski in Svetokret, is rightly considered the most successful Yugoslav avant-garde magazine. In almost six years of its existence (1921-1926), its editor Ljubomir Micić published a plethora of program texts and manifestos, poetic contributions in original languages, innovative art supplements, and atrocious critiques and polemics. In the process, he established an astonishing network of international contacts. Early on, he established contact with the Berlin circle of Herwarth Walden as well as Ehrenburg and El Lissitzky, and he even made the Parisbased poet Yvan Goll a zenitist and coeditor of Zenit. In its heyday, Zenit's international connections extended from Paris, Antwerp, Brussels, and Berlin to Vienna, Krakow, Prague, Budapest, Sofia, Rome, the United States, Russia, Spain, etc.

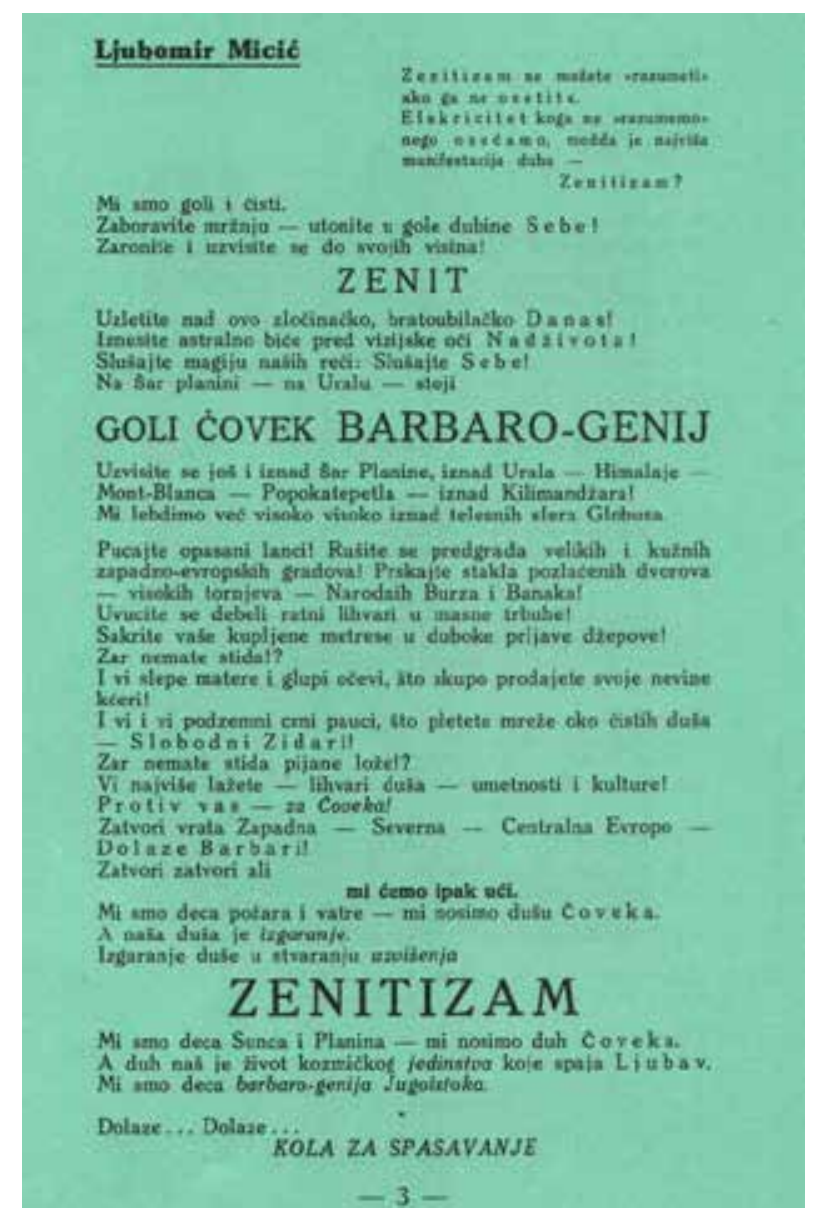

Figure 3. First page of Micić’s „Zenitist Manifesto“ (1921) 
As an avant-garde movement, zenitism was relatively eclectic. It initially fed primarily on (late) expressionist utopianism and partly futurist dynamism, to which it added individual elements of other movements in a syncretic manner. Already in his manifesto of 1921 - the first book published by the ambitious Zenit Library and containing separate texts by Micić, Yvan Goll, and Boško Tokin-Micić closely linked zenitism with the Balkans. He wanted to distinguish the new movement with the idea of Balkan barbarism: „In the Šar Mountains-in the Ural Mountains-there is a NAKED MAN BARBARIAN-GENIUS standing" (Micić, 1921: 3). The idea of the barbarian, which had already been a classic avant-garde topos since Marinetti, takes an original turn in Micić's work: for many centuries the (Serbian) Balkans were considered the defender of Europe against the barbarians (heretics), and now they stood as the defender against decadent Europe, an ,old whore." Moreover, barbarism embodies a new, creative force from the periphery that will invade the rotten core of Europe in order to purify it: „Close the gate ... Europe, but we are going to enter anyway" (ibid.). Thus, a zenitist positions himself as a European savage by analogy with the Russian avant-garde, especially Alexander Blok (cf. Kralj, 1986). Only the Balkan savage, Poljanski claims in a later manifesto from the Tumbe (Upside down) collection (1926), can be truly „authentic,“ whereas Western artists, even if they reach for the spirit of the „savage,“ can only produce tasteless „European lemonade“ that causes vomiting (Poljanski, 1988: 9).

With the concept of the barbarian-genius, zenitism certainly wanted to overcome inferiority complexes vis-à-vis the Western avant-gardes. At the same time, it wanted to establish itself as a relevant European movement in the broad spectrum of postwar -isms precisely through „Balkanisation.“ For this reason, it directed its ambitious gaze in all directions - even to nearby Ljubljana. The first mention of Slovenian events appears in Makroskop (Macroscope), a permanent column of Zenit, which reports on Svetokret in its March issue. Of particular interest is the April issue of Zenit, which contains the unsigned article „Film slovenačke culture“ (The Film of Slovenian Culture). Its author can be none other than the agile Virgil Poljanski, who, as his signatures in the first three issues of Zenit show, was at that time moving between Ljubljana, Zagreb, and Vienna.

„The Film of Slovenian Culture“ is an unsparing, scathing critique of the Ljubljana art scene, its representatives, and its institutions. Cankar, „the only strong personality“ in expressionless Ljubljana, had sadly passed away, but Poljanski remains rudely sarcastic about those still alive. Alojzij Kraigher opens „, shells in which there are no pearls"before the viewer's eyes, Angelo Cerkvenik „writes, but what he writes cannot yet be determined," and Izidor Cankar lectures on expressionism, of which „he knows absolutely nothing.“ Fran Govekar is only a „very bad journalist,“ and for Ivan Tavčar and Ivan Vaupotič, who publicly exposed themselves as opponents of the November Movement, Poljanski hardly finds a word (Zenit 1921/3: 12). 


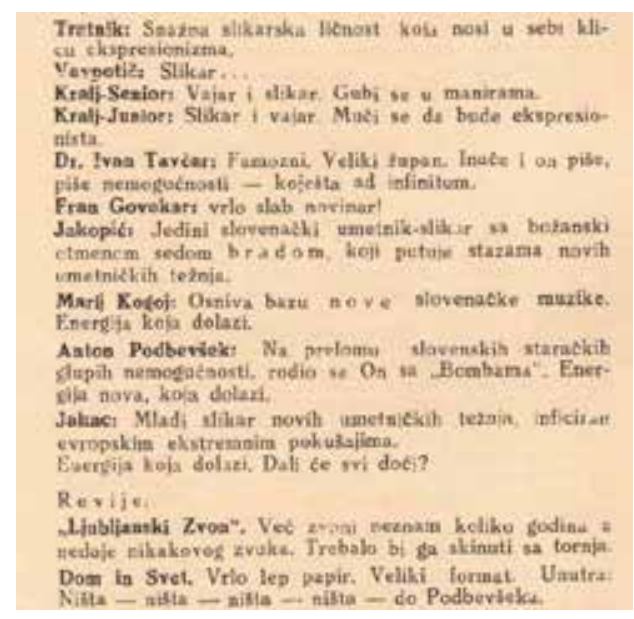

\section{Figure 4. „The Film of Slovenian Culture“ (excerpt), Zenit 3 (April 1921), p. 12}

Most interesting is there assessment of the representatives of the new Slovenian art. Poljanski still appreciates the Impressionist Rihard Jakopič, the patron of young painters („The only Slovenian artist-painter with a divinely elegant gray beard, treading the paths of new artistic trends“), and Fran Tratnik (,A strong painter who carries the germ of Expressionism"). His reservations about Božidar Jakac have also been overcome (,A young painter of new artistic aspirations, infected by European extremes. The energy that comes."). Surprisingly, however, this time he is far less enthusiastic about the Kralj brothers („King-Senior: Sculptor and painter. Loses in manners. King-Junior: Painter and sculptor. Struggles to be an expressionist"). Although Marij Kogoj retains a prominent position („He creates the basis of the new Slovenian music. The energy that is coming."), his attitude toward Anton Podbevšek is turned upside down (,At the turn of the old Slovenian stupid impossibilities, he was born with the 'bombs'. New energy is coming."). The positive opinion about Podbevšek is also supported by witty comments on the most important Slovenian literary magazines: while Ljubljanski zvon (The Ljubljana Bell) has been ringing for years „,without making any sound,“ its rival Dom in svet (Home and World) is only rated better thanks to a young contributor from Novo Mesto: „Very nice paper. Large format. Inside: Nothing—nothing—nothing-to Podbevšek" (ibid.: 12). Poljanski thus proves to be a highly capricious critic.

The friendly atmosphere between the avant-garde circles in Zagreb and Ljubljana in the spring of 1921 is also documented by Podbevšek's correspondence with Poljanski. It seems that Kogoj and Podbevšek were in contact with Zenit and that Poljanski wanted to win Rihard Jakopič to the zenitist cause. From the first postcard sent on the $2^{\text {nd }}$ April, one can learn that the group from Ljubljana was interested in 
Zenit. Podbevšek and Kogoj also announce their imminent arrival in Zagreb and ask Poljanski to find them accommodation for two nights. Another letter follows a week later, this time from Novo Mesto, in which Podbevšek praises the third issue of Zenit, which has arrived in the meantime, and expresses his willingness to cooperate with the magazine (Golubović, 1998: 197-200). It is not known whether Podbevšek and Kogoj actually visited Zagreb in the spring of 1921 and met the zenitist brothers, but the fifth issue of Zenit certainly contained „Portret jednog Slovenca“ (Portrait of a Slovenian, Zenit 1921/5:11), drawn by Vinko Foretić (a.k.a. Vis). Podbevšek's facial features can be deduced from it, but there is no evidence other than the resemblance to confirm the identity. The portrait, drawn in the spirit of a futurist or cubist caricature, was later exhibited at the great Zenit exhibition in Belgrade $\left(9^{\text {th }}-19^{\text {th }}\right.$ April, 1924), with a new title: „Čovek sa cigaretom“ (Man with a Cigarette; Subotić, 1995: 71). ${ }^{7}$

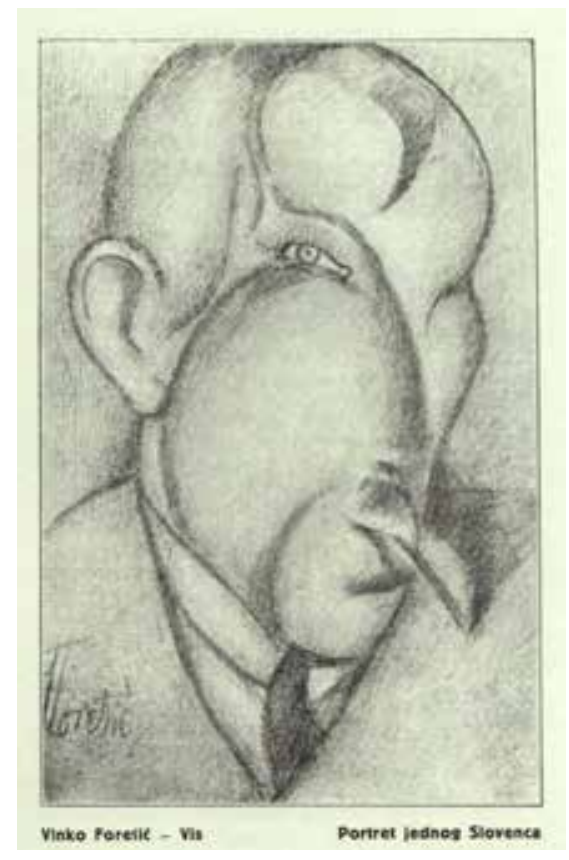

Figure 5. Vinko Foretić, „Portrait of a Slovenian,“ Zenit 5 (June 1921, p. 11)

That the conditions for cooperation between Ljubljana and Zagreb were favourable is attested to by the July issue of Zenit, which reports on the founding of Ljubljana Youth Club and its protagonists, especially the Kralj brothers, who „wage a determined struggle against everything obsolete and inartistic in Slovenia“" (Zenit

7 As part of the Micić collection, the original artwork is now kept by the Belgrade National Museum. 
1921/6: 13). In the September issue, Micić published a photo of the sculpture France Kralj „Težak spomin“ (Grave Memory; Zenit 1921/7: 6), which, as one learns in Makroskop, , gives a spiritual line and contours of the new sculptural art in our country“ (ibid.: 13). Zenit also intended to publish a composition by Kogoj, but this did not materialise „due to technical obstacles“ (ibid.). The November issue praises the recent illustrated book by Fran Kralj, Kralj Matjaž (King Matthias), and the review of the exhibition at the Zagreb Art Pavilion mentions another important future collaborator of Trije labodje and Tank, the painter Veno Pilon:

New unnoticed names that no one has mentioned before should be mentioned. The Slovenian Pilon is an artist whose pen stroke captures deeply and very suggestively in his drawings. The line and the blurred gray concept of his drawings are individual and have the driving force of the modern German artist Meidner. (Zenit 1921/9: 13)

Mutual affection is thus attested, yet the record of Slovenian cooperation is rather modest on the whole: in the first year of Zenit one finds not one poem, not one painting, not one composition by a Slovenian author. This seems difficult to understandbut, as shall be seen, it only became worse later on. While the Slovenian ,youth" were drafting their own magazine in the autumn of 1921, Poljanski was making contacts with European avant-garde artists and staging scandals with Dragan Aleksić in Prague, and in Zagreb Micić instigated the first high-profile dispute within the zenitist movement, which was followed by the departure of notable collaborators such as Boško Tokin, Stanislav Vinaver, Miloš Crnjanski, Rastko Petrović, and Dušan Matić (Golubović and Subotić, 2008: 91-94). The painful mutual accusations revealed that Micić, a stubborn and authoritarian megalomaniac, had serious problems with cooperation.

\section{2: "The swans" and the unsuccessful launch of the Slovenian avant-garde magazine}

At the beginning of 1922, the first issue of Trije labodje was finally published in Ljubljana under the leadership of the trio of Anton Podbevšek, Marij Kogoj, and Josip Vidmar. Trije labodje represents an important stage in the establishment of the new Slovenian art because it brought together a promising group of poets, painters, and composers (cf.Dović, 2020). However, the magazine does not even remotely resemble the daring Zenit. On the contrary, visually it remains traditional, there are no manifestos and controversies in it, and above all its self-sufficiency is remarkable: its focus remains strictly Slovenian. Some parallels with the Zagreb movement can be found in the idea of founding an art publishing house, which also bore the name Trije labodje, reminiscent 
of the bold plans of the Zenit Library. Perhaps they also wanted to imitate Zenit's Makroskop with their feature Listek (Leaflet) - but the contrast could not have been greater. Whereas Zenit agilely and continuously followed the most current impulses from all over the world, the only reference to the foreign avant-garde one can find in Trije labodje is a note about Zenit, written in the patronizing tone typical of Podbevšek:

The only magazine with a progressive ideology under the editorship of Ljubomir Micić and Ivan Goll is being published on the Balkan Peninsula: Zenit. We would welcome it with much greater pleasure if it contained less propaganda and more genuinely artistic contributions because there is a serious danger of discrediting an otherwise interesting artistic movement. Stanislav Vinaver and some of his comrades distanced themselves from Zenit. The reason for this step was the zenitist manifesto of L. Micić. (Trije labodje 1922/1: 30)

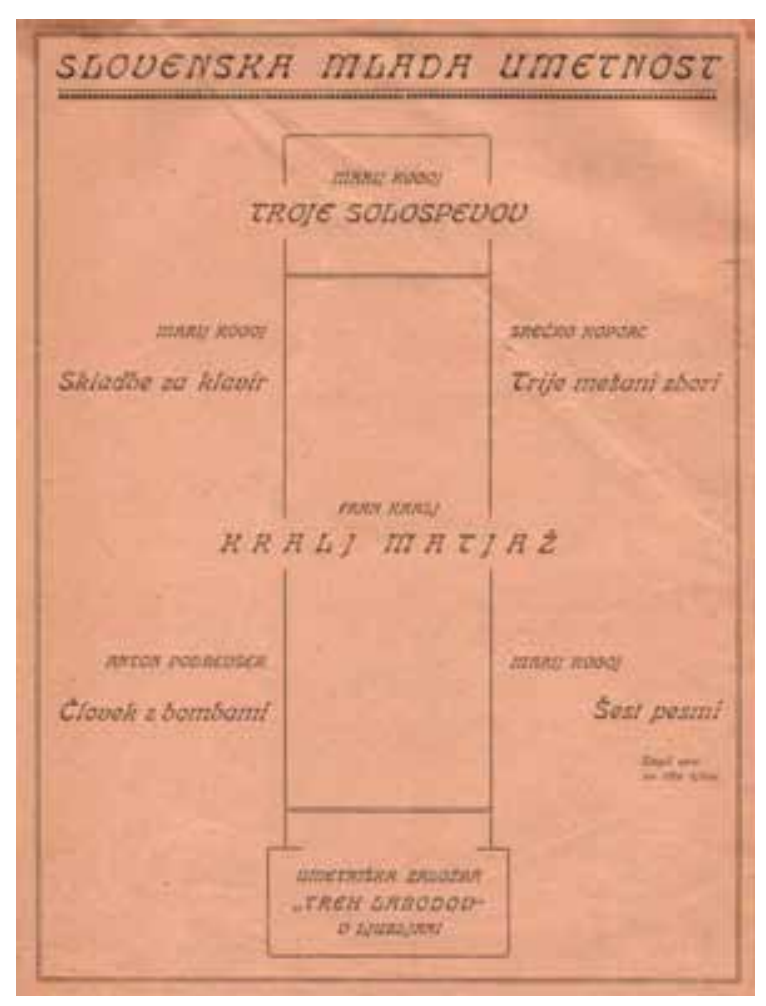

Figure 6. The ambitious plans of „Three Swans Artistic Publishing,“ which were only partially realised (Trije labodje 1922/1) 
Could the slight trace of malevolence visible in this note be the result of personal disputes between Micić and Podbevšek, who, as avant-garde leaders, shared several less pleasant character traits? One can only speculate about this. In any case, the February issue of Zenit mentions the arrival of the first issue of Trije labodje from Ljubljana and names the three editors. This brief note marks the end of the collaboration with the protagonists of the „November Movement“: the zenitists' interest in „expressionless“ Ljubljana has dried up. Already in the spring of 1922, the Micic brothers are found deeply involved in another conflict with one of their former colleagues, this time with the dadaist Dragan Aleksić. The Makroskop column in the May issue reads:

„Angry dog“ (so they called him in Ljubljana after the appearance of Svetokret) Mr.V. Poljanski, who so excellently „throws the lasso around the neck of the Mother of God," threw countless lassos around countless twisted necks in Dada-Jok. . For his anti-Dadaist action with the help of Dadaism itself, Mr. Poljanski deserves to become a member of any Yugoslav Academy and to receive the Zenit medal. (Zenit 1922/14: 32)

Poljanski, who had previously stirred up Ljubljana, obviously caused trouble elsewhere as well: the daring blasphemous poem „Laso materi božjoj oko vrata“ (A Lasso around the Neck of the Mother of God) attracted the attention of the court, and with the Dada-Jok magazine he created a witty „dadaist" parody of dadaism. The show down with Aleksić, one of Zenit's most promising collaborators, once again underscored Micić's authoritarianism. Be that as it may, Zenit remained silent about the second and last issue of Trije labodje, which appeared without Podbevšek, and also about Podbevšek's anarcho-proletarian Rdeči pilot (The Red Pilot), which also comprised only two issues. In 1922, Slovenian "young art" fell completely out of Zenit's field of vision-which remained the case until the magazine was banned. This assessment is hardly challenged by the fact that the June 1922 issue published the short Slovenian dramatic dialogue „V parku“(In the Park), signed by „A. Čebular-Črnomelj,“ which „,bears many similarities to the genre of dramatic synthesis cultivated by the Italian Futurists" (Golubovic and Subotić, 2008: 388). Albin Čebular (1900-1952) is nowadays hardly known as a poet in Slovenia, and his youthful avant-garde episode has so far gone completely unnoticed. 


\section{PARKU}

\section{A. Čebular - Črnomelj}

Rido Pajek: advokat

Fira Repek: guvernanta

Rido Pajek: predstava: trebuhoborba - trde noge vleči v glavi prevračati 30 ulic mačeka lomiti garderoba med klobuki.

Fira Repek: z velikim programom?

Rido Pajek: Da, krava bezljati preko mene - pahniti cestni jarek pasti Novo: plakat kako fižol sejati da črešnje izrastu hvala bogu še dva čika v žepu (naredi cigareto).

Fira Repek: Bomboni bomboni bomboni ... najnovejša moda:

$$
\begin{aligned}
& \text { rdeče-zeleno } \\
& \text { glaseee-sandali } \\
& \text { lakasti-lasje }
\end{aligned}
$$

presičke voditi na vrvi šetati $\mathrm{z}$ njimi po parkih $\mathbf{v}$ PARMI izdelovati prašek glavobolni kosti obirati boli boli...

Rido Pajek: polahko polahko polahko uze popravljati kolešcek ostati možgane logičneje

Fira Repek: logika pokopati zapečatiti hiperlogika uničiti NE razumete me - TEPEC cvetlice $\mathrm{v}$ cvetličnjaku brati iztegati noge kosmate na divanu zajahati solnce. novootvorjena pošta drndati črno. melj LOGATEC svečni

Rido Pajek: Looo... - huuuuu glava odpirati: razumeti u strah polaščati polaščati strah sove sove me strah lase ježiti kavarna kavopiti piti kavo čitati časopise preje nič bati leteti leteti leteti pasti vstati dihati klicati sedeti kaditi cigareto.

Fira Repek: Ojoja oj vi stopite mi na kurje oko!

Rido Pajek: divni razgled: gnojišče mlaka gnili panju

Fira Repek: ah oko oko smrdleči zrak...

Rido Pajek: pardon gospodična! (ji gledati pod noge potem v oči) kaj krastača kamen poleno žemlja motne očali zdravnik vam dati recept za druge.

Fira Repek: predstava 38

Rido Pajek: iti bliskati grmeti muditi frak polikati pravočasno uro pognati godbo odpovedati pijanec opotekati cilinder zakrpati sama iti

Fira Repek: Kost glista štriga trska vagabund ti ...

Rido Pajek: (sam sebi:) Lahkonoč leščerba -

Fira Repek: Jaz na cedilu ostati

Zasior

Figure 7. Albin Čebular, „In the Park,“ the only Slovenian literary text in Zenit $(1922 / 15$, p. 39) 
However, the bottom line is that Čebular's marginal dramatic experiment remains the only Slovenian literary text published in Zenit, and the only Slovenian contribution besides the photograph of France Kralj's sculpture from the previous year. Zenit's periscope, meanwhile, turned decidedly toward the wider world: the Micić brothers forged lively links with the centers of the avant-garde, and Ljubljana was no longer considered a significant focal point of the new art.

\section{April 1925: The "apostle of zenitism" returns to Ljubljana}

The growing problems that the conflicted (and pro-Serb) Micic had with the publication of Zenit in Zagreb led to the transfer of the editorial office to Belgrade in 1923. There the problems continued as the magazine came out less regularly, but the zenitist brothers continued to successfully promote the movement abroad. Contacts with Slovenian avant-garde artists were resumed in 1925, but this time not with representatives of the disbanded „swans, “ but with representatives of the second, „constructivist“ wave. In 1925, Poljanski visited Slovenia again and teamed up with the painter August Černigoj. In April, they held a zenitist evening in Trbovlje, for which Černigoj created a scenography that has not been preserved (Štoka, 1999: 73). The climax followed on the $23^{\text {rd }}$ April; 1925, when Poljanski staged a bombastically announced and well-attended zenitist evening at Ljubljana City Hall. An unsigned report was published the next day:

At last the excitement in the hall has died down, and the „man with the strongest imagination in Europe" took the stage and apologised in the introduction for the American-style advertising.. . . Branko Ve Poljanski now began to explain what zenitism means, who its founder is, what its history is, and what its goal is, which he summed up in the sentence that each of us must strive to become a „barbarian-genius.“(Podbevšek, 1925: 4)

In the writer one can undoubtedly recognise the former charismatic leader of the young Slovenian poets, who was then working as a reporter for the Jutro newspaper. Podbevšek is quite taken with the ,apostle“ of zenitism, who „shook up otherwise peaceful Ljubljana“:,,Several statements were met with loud applause because Poljanski did not spare paradoxes“ (ibid.). However, his enthusiasm is not unqualified: If the „fakir from the Balkans“ was interesting to level-headed youth, he appealed far less to the „connoisseurs“ because ,they heard the same thing so often that they already had a headache" (ibid.). Podbevšek, who published his only volume of poetry, Človek $z$ bombami (The Man with the Bombs), in 1925, was apparently withdrawing from the avant-garde trenches. 


\section{Zenitistični večer senzacije.}

Mestni dom v četrtek ob 8. uri zvečer.

Branke Ve Pollanst! Branke Ve Pollansal Branke Ve Pollamki! Branke Ve Pollansk Branke Ve Polland! Branke Ve Pollaird! Branko Ve Poljanskj Branko Ve Poljanski Branko Ve Poljansi. Branke Ve Pollanski Mranko Ve Poljandil Ilranke Ve Pollanski Branko Ve Pollanski Branke Ve Pollantai Branke Ve Pollanski Branke Ve Pollandil Branko Ve Poljanski Branko Ve Pollanshi Branke Ve Polbanki Branke Ve Pollandi Braake Ve Pollandi Branko Ve Pollanskl Branko Ve Pollansi Branke Ve Polhansi Branko Ve Pollanski Branke Ve Pollanski Branko Ve Pollanski Branke Ve Pollansk! Branko Ve Pollanski Branko Ve Pollansa! Branko Ve Pollanst Branko Ve Poljand! Branke Ve Potlansa! Branke Ve Polanal Branke Ve Poljansk| Branko Ve Pollamk! Branke Ve Pollanaki
Nikdar be alsemo zledall $v$ Lubljani. Nudar le alsano posduball v Lubliani. Stedentl in madici!

Babe in devolke!

Zallablfesed in samomoriki!

Prolesoril in izraki!

Pevd in dokteris!

Stardi in deca!

Pridite va y Mestal de rveder ob \& da boste postulall pesalka aeverkinllh Cudetev:

4a boste videl Clereka, $z$ najmoknejiso fantaxllo \& Evfopl:

Pesak vam bo pripovedoval o zenitimeu kot novi umetnostl na svetu.

Bral van be pesent, kakriolh ie wiste nlkdx slikall.

Zealtirem se buri a većno mladost! Zeditixen se bori za balksalraclip Evrope! Zenitixem se borl za ravo sulith aad debelinal!

Zenlitirem se borl protl oslaril y Evrepi! Zeeditixen se borl za ustvarlitev noveza svela! Zenlitzem se borl za nove stkarsiva! ZENITIZEM za nove poerlilo:

ZENITIZEM za nove zledallide! ZENITIZEM za novo arhitekturo: ZENITIZEM za srobodo la veselle usivarjania barbaro-kenilla!

Stari is mbdi! Lepi in srdit Pametni in bedasti! Motki in tenske! Pridlte vil as ta veler senacile, da beste sliball in videll balkandeza fakirja te Cloveka $a$ adrecko lantazllo stareza in soveca sveta

Branka Ve Poljanskega.

Zealtixea k kontrapolitileni pokret. zate pridite vil, brez razlike strank:

\section{D Živel zenitizem:}

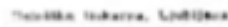

Figure 8. A flyer for Poljanski's „Zenitist evening of sensation“ in Ljubljana on the $\mathbf{2 3}^{\text {rd }}\left(\right.$ April, 1925) ${ }^{8}$

Srečko Kosovel also attended the zenitist soirée. His attitude toward zenitism was ambivalent: in his diary entries of 1924 he faithfully followed zenitist ideas and accepted the notion of barbarism that would revive decaying European art with fresh Balkan energy, but at the time of Poljanski's lecture-despite his fascination with the speaker-he already felt a certain skepticism (Vrečko, 2012: 265-267). Here, however, it seems more important to emphasise something else; namely, that access to Zenit was by far the most important window for the young poet into the world of avant8 Golubović and Subotić, 2008: 207. 
garde art, its manifestos, and creative practices. Although Zenit was (also) a mouthpiece of a particular avant-garde formation, it did not lose its comprehensive cosmopolitan character, especially in the early years: it offered a unique source of information on virtually all relevant events of the avant-garde not only of the West, but also of the East and the South (cf. the zenitist slogan orient-occident). In this sense, one should not forget that Zenit's fundamental role for the Slovenian avant-garde was to broaden horizons and provide inspiration.

\section{6-1927: The decline of Zenit and the rise of Tank}

The interest in zenitism among the representatives of the second wave of the Slovenian interwar avant-garde (especially Černigoj, Kosovel, and the theatre director Ferdo Delak) opened new possibilities. During this period, the Slovenian „constructivists“ welcomed the zenitist ideas and slogans with open arms, as evidenced by the joint manifesto of Delak and Černigoj published in Mladina in the autumn of 1926, in which one reads, among other things: „We want to be barbarian-geniuses. This is the slogan of Balkan nature, we want to live in harmony with the whole world in a dynamic form of activism" (Delak, 1926: 21). The collaboration intensified when Zenit suffered a fatal blow at the hands of (anti-communist) censorship in Belgrade and its editor was dramatically evacuated to Paris via Rijeka, with even Marinetti intervening.

In the first half of 1927, Micic tried to revive the movement and its magazinein either Paris, Belgrade (via Marijan Mikac), or Ljubljana—but his success was meagre at best. He also pinned his hopes on the Slovenian constructivists, as is evident from Černigoj's preserved letter to Micić. The Slovenian avant-garde artists saw themselves as the spiritual successors of zenitism: ,We barbarians, “wrote Černigoj on the $3^{\text {rd }}$ March, 1927, ,are more skillful and artistically gifted than all French-Italian and German commercial prostitution" (Golubović, 1987: 102). Their self-confidence gradually grew: the zenitist activities had earlier represented a difficult-to-attain role model for them, but Micić was now gradually losing the leading role. On the $2^{\text {nd }}$ September, he received a note in Paris that Delak and Černigoj would publish an "activist magazine" in Ljubljana, with sub-offices in „Germany (Hannes Meyer in Dessau), Italy (Sofronio Pocarini in Gorizia), Switzerland (Jean Bard in Geneva, etc.)," and Micić, the „originator of zenitism," was asked to be the editor for France and Serbia (ibid.: 100). 


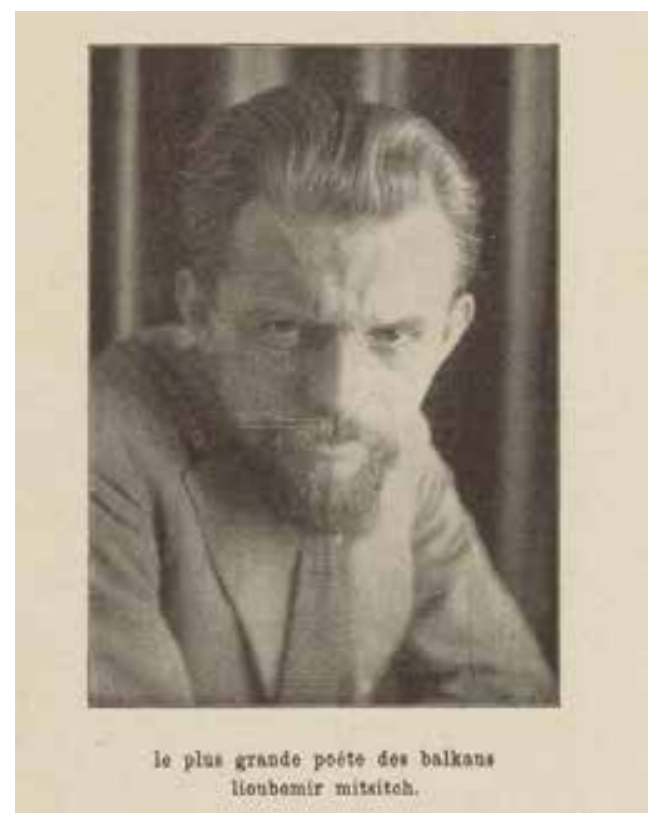

\section{Figure 9. Ljubomir Micić, „le plus grande [sic!] poète des balkans“} (Tank 1927/1/2, p. 11)

Micić, who „hoped and believed that the Slovenian avant-garde artists, especially Ferdo Delak and Avgust Černigoj, would continue with Zenitism" (Subotić, 1995: 81), really had no choice but to participate in the project. He may have accepted the new, subordinate role so much more easily because the „tankists" dubbed him „the greatest poet of the Balkans.“ They had good reasons to flatter the narcissistic megalomaniac: even a cursory glance at Tank's published issues shows that the new magazine drew not only on the ideological legacy of zenitism and its banned magazine, but also on a valuable network of foreign collaborators that the Micić brothers had forged by then. This is why from the outset Tank was able to be remarkably different from Trije labodje, for example: it was decidedly modern and, by Slovenian standards, downright fascinatingly international. ${ }^{9}$

With Tank, the protagonists of the second wave of the Slovenian historical avant-garde finally became actively associated with zenitism. Moreover, a group of Slovenian artists, under the tutelage of the ambitious Delak, who called himself the „directeur" of the new „movement artistique d'avant-garde international,“ placed themselves at the forefront of Yugoslav progressive art.

9 For the connections between Tank and Zenit, cf. Poniž (1987), Golubović (1987), Ilich Klančnik and Zabel (1999), and Dović (2016). 
The zenitist Marijan Mikac commented on the publication of Tank's first edition in a letter to Micić:

Tank deserves congratulations for its courage and good will, but it seems to me that the young people around Tank are not capable of producing new works. They can be a sensation for Slovenia, maybe not even that anymore. I want to be wrong, but this is the impression I got from the first issue of Tank, although it is technically excellent. (Golubović and Subotić, 2008: 250)

The above assessment is incompetent and unfair in at least one point: Tank's visual faction, especially Černigoj's constructivists, certainly proved capable of creating important new works. Nevertheless, it turned out that the ,revue internationale de l'art vivant," which was trying to penetrate the world through the zenitist niche, did not have enough momentum. Even before the tankists could build up the necessary base of Slovenian collaborators and consolidate the material conditions for a more serious publication, after two promising issues Tank fell victim to bureaucratic obstacles, behind which one can sense the ideological and censorial resistance that had already buried Zenit.

Meanwhile, other avant-garde protagonists were slowly cooling off. The hated and ostracized Podbevšek finally withdrew from public life in 1927. That same year, Poljanski gave up poetry and disappeared into the Parisian painting scene, and Micić, nostalgic for the heroic past of zenitism and increasingly open to nationalist ideas, also lost momentum. Delak's success as a representative of „young Slovenian art" in Herwarth Walden's Der Sturm (The Storm) in January 1929-a consecration of the movement by the decadent West-came too late to mean anything more than a retrospective of a turbulent postwar utopia.

\section{REFERENCES:}

1. Delak, Ferdo. 1926. „Avgust Černigoj.“Mladina 3(1), 19-23.

2. Dović, Marijan. 2009. Možz bombami: Anton Podbevšek in slovenska zgodovinska avantgarda. Ljubljana, ZRC SAZU; Novo Mesto: Založba Goga.

3. Dović, Marijan. 2016. „From autarky to 'barbarian' cosmopolitanism: the early avantgarde movements in Slovenia and Croatia," in: Adam J. Goldwyn and Renée M. Silverman: Mediterranean Modernism. New York: Palgrave Macmillan. 233-250.

4. Dović, Marijan. 2020. „Podbevškova pesniška šola, Trije labodje in zaton 'bombaša'.“ Slavistična revija 68(3), 427-440.

5. Đurić, Dubravka M. 2012. „Poetika hibridnih multižanrovskih pesničkih tekstova Ljubomira 
Micića i BrankaVe Poljanskog.“ Poznańskie Studia Slawistyczne 2, 119-133.

6. Golubović, Vida. 1987. „Dopisovanje v zvezi z revijo Tank. Černigoj - Delak - Micić,“ In: Tank. Ljubljana: Mladinska knjiga. 96-113.

7. Golubović, Vidosava. 1998. „Iz prepiske oko Zenita i zenitizma.“ Ljetopis Srpskog kulturnog društva Prosvjeta 3, 197-209.

8. Golubović, Vidosava, and Irina Subotić. 2008. Zenit: 1921-1926. Belgrade/Zagreb: Narodna biblioteka Srbije, Institut za književnost i umetnost; Srpsko kulturno društvo Prosvjeta.

9. Ilich Klančnik, Breda and Igor Zabel (eds.). 1999. Tank! Slovenska zgodovinska avantgarda. Ljubljana: Moderna galerija.

10. Konstantinović, Radomir. 1983. „Branko Ve Poljanski.“Biće i jezik, Vol. 6. Belgrade: Nolit, Rad; Novi Sad: Matica srpska. 469-506.

11. Kralj, Lado.1988. ,'Jaz sem barbar’. Barbarstvo kot motiv in ideologija v avantgardistični literaturi." Primerjalna književnost 11(1), 29-41.

12. Micić, Ljubomir. 1921. „Manifest zenitizma,“ In: Ljubomir Micić, Ivan Goll, and Boško Tokin, Manifest zenitizma. Zagreb: Biblioteka Zenit.

13. Podbevšek, Anton [Anon.]. 1925. „Zenitistični večer Poljanskega.“ Jutro 6 (96), 24 April, 4.

14. Poljanski, Branko Ve. 1988. Panika pod suncem. Tumbe. Crveni petao. Facsimile edition. Ed. Aleksandar Petrov. Belgrade: Narodna biblioteka Srbije.

15. Poljanski, Virgil. 1921. Svetokret. List za ekspediciju na severni pol čovekovog duha. Ljubljana: [Zvezna tiskarna].

16. Poniž, Denis.1987. „Revija Tank in slovenska likovna avantgarda,“ In: Tank. Ljubljana: Mladinska knjiga. 57-74.

17. Rogić Musa, Tea. 2010. „Utopijski diskurs u književnoj avangardi: Svetokret i Dada-Jok Branka Ve Poljanskog.“ Studia lexicographica 4(2), 59-75.

18. Štoka, Tea. 1999. „Ferdo Delak in poskus avantgardističnega gledališča,“ In: Breda Ilich Klančnik and Igor Zabel (eds.): Tank! Slovenska zgodovinska avantgarda. Ljubljana: Moderna galerija. $66-76$.

19. Subotić, Irina. 1995. Likovni krog revije “Zenit” (1921-1926). Ljubljana: Filozofska fakulteta.

20. Svetokret. [1921].

21. Tank. [1927].

22. Todorović, Predrag. 2015. „Život i smrt Branka Ve Poljanskog.“ Književna istorija 46 (154), $1007-1015$.

23. Trije labodje. [1922].

24. Vrečko, Janez. 2012. „Barbarogenij, barbarsko in fašizem.“ Primerjalna književnost 35 (3), 261-270.

25. Zenit. [1921-1926]. 
Od Svetokreta do Tanka: zenitizam i slovenačka međuratna avangarda (1921-1927)

Apstrakt: Ujanuaru 1921. godine u Ljubljani, Virgil Poljanski(1898-1947) je pokrenuo Svetokret, prvi radikalni avangardni časopis u novoosnovanoj Kraljevini Srba, Hrvata i Slovenaca. Ovo jedinstveno izdanje je bilo najava Zenita (1921 - 1926), glasnika ambicioznog zenitističkog pokreta, koji je oličio stariji brat Poljanskog Ljubomir Micić (1895 - 1971). Ovaj članak ispituje dinamiku odnosa između protagonista slovenačke međuratne avangarde i vodećih zenitista, kako je dokumentovano u prepisci, novinskim izveštajima, i, pre svega, u časopisu i izdavačkoj produkciji samih avangardnih pokreta. U prvoj fazi, ti odnosi su se vrteli oko Antona Podbevšeka i njegove grupe koja se okupljala oko časopisa Trije labodje (Tri labuda, 1922.), ali saradnja je i dalje bila ograničena. U drugoj, produktivnijoj fazi, zenitističke ideje je delimično prihvatila grupa slovenačkih konstruktivista koju su predvodili Avgust Černigoj i Ferdo Delak. Zenitizam i njegov časopis zasigurno su bili važan izvor informacija i inspiracija slovenačkim umetnicima avangarde (npr. pesniku Srečku Kosovelu), ali, uprkos nekolicini pokušaja, saradnja nije dala trajne rezultate pre nego što je Zenit zabranjen 1926. godine. Ljubljanski časopis Tank, čiji je urednik bio ambiciozni Delak, a koji je podržao Micić, 1927. godine, pokušao je da nastavi zenitističko nasleđe. Nažalost, njegovo postojanje je bilo kratkog veka.

Ključne reči: Svetokret, Zenit, Tank, slovenačka međuratna avangarda, zenitizam. 